\title{
Genistein and zinc synergistically enhance gene expression and mineralization in osteoblastic MC3T3-E1 cells
}

\author{
SATOSHI UCHIYAMA and MASAYOSHI YAMAGUCHI \\ Laboratory of Endocrinology and Molecular Metabolism, Graduate School of Nutritional Sciences, \\ University of Shizuoka, 52-1 Yada, Suruga-ku, Shizuoka 422-8526, Japan
}

Received June 27, 2006; Accepted August 29, 2006

\begin{abstract}
Genistein, a phytoestrogen, and zinc, an essential trace element, have an anabolic effect on bone components. We investigated whether the combination of genistein and zinc has additive and synergistic effects in osteoblastic cells in vitro. Osteoblastic MC3T3-E1 cells with subconfluency were cultured for $48 \mathrm{~h}$ in medium containing either vehicle, genistein $\left(10^{-6}\right.$ or $\left.10^{-5} \mathrm{M}\right)$, zinc sulfate $\left(10^{-5}\right.$ or $\left.10^{-4} \mathrm{M}\right)$ or genistein $\left(10^{-6}\right.$ or $\left.10^{-5} \mathrm{M}\right)$ plus zinc sulfate $\left(10^{-5}\right.$ or $\left.10^{-4} \mathrm{M}\right)$. The protein content in the osteoblastic cells was significantly increased in the presence of genistein $\left(10^{-5} \mathrm{M}\right)$ or zinc $\left(10^{-4} \mathrm{M}\right)$. This increase was significantly enhanced with a culture of genistein $\left(10^{-5} \mathrm{M}\right)$ plus zinc $\left(10^{-4} \mathrm{M}\right)$. The expression of mRNAs of $\alpha 1$ (I) collagen and osteocalcin, which are bone matrix protein, in osteoblastic cells was demonstrated using reverse transcription-polymerase chain reaction (RT-PCR) analysis with a specific primer. This expression was not significantly increased with genistein $\left(10^{-6}\right.$ or $\left.10^{-5} \mathrm{M}\right)$ or zinc $\left(10^{-5}\right.$ or $\left.10^{-4} \mathrm{M}\right)$. The combination of genistein $\left(10^{-6}\right.$ or $\left.10^{-5} \mathrm{M}\right)$ and zinc $\left(10^{-5}\right.$ or $\left.10^{-4} \mathrm{M}\right)$ caused a significant increase in $\alpha 1(\mathrm{I})$ collagen and osteocalcin mRNA expression in osteoblastic cells. Alkaline phosphatase mRNA expression in osteoblastic cells was significantly enhanced with a culture of genistein $\left(10^{-5} \mathrm{M}\right)$ plus zinc $\left(10^{-4} \mathrm{M}\right)$. The effect of genistein $\left(10^{-5} \mathrm{M}\right)$ plus zinc $\left(10^{-4} \mathrm{M}\right)$ in enhancing the expression of $\alpha 1(\mathrm{I})$ collagen, alkaline phosphatase, or osteocalcin mRNAs in osteoblastic cells was completely prevented with a culture of cycloheximide $\left(10^{-7} \mathrm{M}\right)$, an inhibitor of protein synthesis, or 5,6-dichloro-1-ß-D-ribofuranosylbenimidazole (DRB) $\left(10^{-6} \mathrm{M}\right)$, an inhibitor of transcriptional activity. Moreover, a culture with genistein $\left(10^{-5} \mathrm{M}\right)$ or zinc $\left(10^{-4} \mathrm{M}\right)$ for 14 or 21 days caused a significant increase in mineralization. This increase was markedly enhanced with a culture of the
\end{abstract}

Correspondence to: Dr Masayoshi Yamaguchi, Laboratory of Endocrinology and Molecular Metabolism, Graduate School of Nutritional Sciences, University of Shizuoka, 52-1 Yada, Suruga-ku, Shizuoka 422-8526, Japan

E-mail: yamaguch@u-shizuoka-ken.ac.jp

Key words: genistein, zinc, $\alpha 1(\mathrm{I})$ collagen, osteocalcin, mineralization, osteoblast combination of genistein $\left(10^{-5} \mathrm{M}\right)$ and zinc $\left(10^{-4} \mathrm{M}\right)$. This study demonstrates that the combination of genistein and zinc can synergistically enhance gene expression and mineralization in osteoblastic cells.

\section{Introduction}

Bone mass decreases with increasing age. Decrease in bone mass induces osteoporosis, which is widely recognized as a major public health problem. The most dramatic expression of this disease is represented by fracture of the proximal femur (1-3). Decrease in bone mass is due to increased bone resorption and reduced bone formation. Pharmacological and nutritional factors may prevent bone loss with increasing age $(4,5)$. Chemical compounds in food that act on bone metabolism, however, are poorly understood.

Genistein is a natural isoflavonoid phytoestrogen found in Leguminosae and has been demonstrated to have an anabolic effect on bone metabolism, suggesting a role in the prevention of osteoporosis (reviewed in ref. 6). Genistein has a stimulatory effect on bone formation and mineralization $(7,8)$ and an inhibitory effect on osteoclastic bone resorption $(9,10)$. The dietary intake of genistein prevented bone loss in ovariectomized rats which are model animals of osteoporosis (11). Genistein is a useful biofactor in the prevention of osteoporosis.

Zinc, an essential trace element, has been demonstrated to have a potent stimulatory effect on osteoclastic bone formation $(12,13)$ and an inhibitory effect on osteoclastic bone resorption $(14,15)$. Zinc can stimulate protein synthesis in osteoblastic cells in vitro by activating aminoacyl-tRNA synthetase (16). The oral administration of a zinc compound prevented bone loss in an animal model of osteoporosis (17).

Whether the combination of nutritional factors reveals an additive or synergistic effect on bone components has not been fully determined. This knowledge may be important in the prevention of bone loss with increasing age. Recently, it has been shown that the combination of genistein and zinc has a synergistic effect on bone components in the femoral tissues of rats (18-20). Moreover, it has been demonstrated that the preventive effect of dietary fermented soybean on bone loss is enhanced by supplementation of isoflavone and zinc in ovariectomized rats (21). The intake of dietary genistein and zinc-supplemented fermented soybean has a stimulatory effect on serum bone-formation markers and a suppressive effect on serum bone-resorption markers in aged men and women (22). 
The cellular mechanism by which the combination of genistein and zinc has an additive and/or synergistic effect on bone metabolism has not been clarified. This study was undertaken to determine the effect of genistein and zinc on gene expression and mineralization in osteoblastic cells in vitro.

\section{Materials and methods}

Chemicals. $\alpha$-minimal essential medium ( $\alpha$-MEM) and penicillin-streptomycin $(5000 \mathrm{U} / \mathrm{ml}$ penicillin; $5000 \mu \mathrm{g} / \mathrm{ml}$ streptomycin) were obtained from Gibco Laboratories. Fetal bovine serum (FBS) was obtained from Bioproducts Inc. Cycloheximide, and 5,6-dichloro-1-ß-D-ribofuranosylbenzimidazole (DRB), were obtain from Sigma Chemical Co. Zinc sulfate and other chemicals were of reagent grade and were obtained from Wako Pure Chemical Industries. All water used was glass distilled. Tissue culture plastic dishes were purchased from Falcon Plastics. Other materials used were commercial products of the highest grade available.

Cell culture. Osteoblastic MC3T3-E1 cells were cultured at $37^{\circ} \mathrm{C}$ in a $\mathrm{CO}_{2}$ incubator in plastic dishes containing $\alpha$-MEM supplemented with $10 \%$ FBS. They were subcultured every 3 days using $0.2 \%$ trypsin plus $0.02 \%$ EDTA in $\mathrm{Ca}^{2+} / \mathrm{Mg}^{2+}$ free phosphate-buffered saline (PBS). For the experiments, $1.0 \times 10^{5}$ cells per dish were cultured for 3 days to obtain subconfluent monolayers in 35-mm plastic dishes containing $2 \mathrm{ml}$ $\alpha$-MEM with $10 \%$ FBS. After the cells were rinsed with PBS, the medium was exchanged for medium without FBS containing either vehicle, genistein, zinc sulfate, or genistein plus zinc sulfate in the presence or absence of various inhibitors, and the cells were cultured for an additional 24 or $48 \mathrm{~h}$. Cell viability was estimated by staining with trypan blue.

Cell counting. After trypsinization of the cells in each culture dish using a Ca ${ }^{2+} / \mathrm{Mg}^{2+}$-free PBS containing $0.2 \%$ trypsin and $0.02 \%$ EDTA for $2 \mathrm{~min}$ at $37^{\circ} \mathrm{C}$, cells were collected and wash-centrifuged in a PBS solution at $100 \mathrm{x}$ g for $5 \mathrm{~min}$. The cells were re-suspended in a $0.5 \mathrm{ml}$ PBS solution, and an aliquot was stained with eosin. The cells were counted under a microscope using a Hemocytometer plate. For each dish, we took the average of two counts.

Analytical procedures. To determine the protein concentration in the osteoblastic cells, the cells were washed 3 times with PBS, scraped into $0.5 \mathrm{ml}$ of ice-cold $0.25 \mathrm{M}$ sucrose solution, and disrupted for $30 \mathrm{sec}$ with an ultrasonic device. The protein concentration in the cell homogenate was determined by the method of Lowry et al (23) and expressed as the amount of protein $(\mu \mathrm{g})$ per dish.

To assay alkaline phosphatase activity in the cells after the appropriate treatment periods, the cells were washed 3 times with PBS, scraped into $0.5 \mathrm{ml}$ of ice-cold $0.25 \mathrm{M}$ sucrose solution, and disrupted for $30 \mathrm{sec}$ with an ultrasonic device. The supernatant, centrifuged at $600 \mathrm{x} \mathrm{g}$ for $5 \mathrm{~min}$, was used to measure enzyme activity. The enzyme assay described below was carried out under optimal conditions. Alkaline phosphatase activity was determined by the method of Walter and Schutt (24). The enzyme activity was expressed as nmol of $p$-nitrophenol liberated/min/mg of protein.
Determination of specific mRNA by $R T-P C R$. Total RNAs were prepared as described previously (25). Osteoblastic MC3T3-E1 cells with subconfluency were cultured for 24 or $48 \mathrm{~h}$ in medium containing either vehicle genistein, zinc sulfate, or genistein plus zinc sulfate. After culturing, cells were washed 3 times with ice-cold PBS, and then the cells were homogenized in a buffer solution containing $4 \mathrm{M}$ guanidinium thiocyanate, $24 \mathrm{mM}$ sodium citrate $(\mathrm{pH} 7.0)$, $0.5 \%$ sarcosyl, and isoamyl alcohol, and the phases were separated by centrifugation at $10,000 \mathrm{x}$ g for $20 \mathrm{~min}$ at $4^{\circ} \mathrm{C}$. RNA located in the aqueous phase was precipitated with isoprepanol at $-20^{\circ} \mathrm{C}$. RNA precipitates were pelleted by centrifugation, and the pellets were redissolved in diethylpyrocarbonate-treated water.

Reverse transcription-polymerase chain reaction (RTPCR) was performed with a Titam $^{\mathrm{TM}}$ one tube RT-PCR kit (Roche Molecular Biochemicals) as recommended by the supplier. Primers for amplification of mouse Runx 2 cDNA were: 5'-GTATGAGAGTAGGTGTCCCG-3' (sense strand, positions 992-1011 of cDNA sequence) and 5'-ACATCCCC ATCCATCCACTC-3' (antisense strand, positions 11561175) (26). The pair of oligonucleotide primers was designed to amplify a 183-bp sequence from the mRNA of mouse Runx2. Primers for amplification of mouse $\alpha 1$ (I) collagen cDNA were: 5'-TTCTCCTGGTAAAGATGGTGC-3' (sense strand, positions 2232-2252 of cDNA sequence) and 5'-GG ACCAGCATCACCTTTAACA-3' (antisense strand, positions 2466-2486) (27). The pair of oligonucleotide primers was designed to amplify a 254-bp sequence from the mRNA of $\alpha 1$ (I) collagen. Primers for amplification of mouse alkaline phosphatase cDNA were: 5'-GGCTTCTTCTTGCTGGTGG A-3' (sense strand, positions 1158-1177 of cDNA sequence) and 5'-TGAGCGACACGGACAAGAAG-3' (antisense strand, positions 1387-1406) (28). The pair of oligonucleotide primers was designed to amplify a 244-bp sequence from the mRNA of alkaline phosphatase. Primers for amplication of mouse osteocalcin cDNA were: 5'-GGGG AAGGGACAACACATGA-3' (sense strand, positions 188-207 of cDNA sequence) and 5'-TCCTGGACATGGGGATTGA C-3' (antisense strand, positions 580-599) (29). The pair of oligonucleotide primers was designed to amplify a 412-bp sequence from the mRNA of osteocalcin. For semi-quantitative PCR, glyceraldehyde-3-phosphate dehydrogenase (G3PDH) was used as an internal control to evaluate total RNA input. Primers for amplification of G3PDH cDNA were: 5'-GAT TTGGCCGTATCGGACGC-3' (sense strand) and 5'-CTCC TTGGAGGCCATGTAGG-3' (antisense strand). The pair of oligonucleotide primers was designed to amplify a 977-bp sequence from the mRNA of rat G3PDH. RT-PCR was performed using a reaction mixture $(25 \mu \mathrm{l})$ containing 2 or $4 \mu \mathrm{g}$ of total RNAs, supplied RT-PCR buffer, Titam ${ }^{\mathrm{TM}}$ enzyme mix (AMV and Expand ${ }^{\mathrm{TM}}$ High Fidelity), $0.2 \mathrm{mM}$ dNTP, $5 \mathrm{mM}$ dithiothreitol, $5 \mathrm{U}$ RNase inhibitor, and $0.3 \mathrm{mM}$ primers. Samples were incubated at $50^{\circ} \mathrm{C}$ for $30 \mathrm{~min}$, and then amplified for 35 cycles under the following conditions: denaturation for $30 \mathrm{sec}$ at $94^{\circ} \mathrm{C}$, annealing for $30 \mathrm{sec}$ at $56^{\circ} \mathrm{C}$, and extension for $60 \mathrm{sec}$ at $68^{\circ} \mathrm{C}$. The amplified products were separated by electrophoresis on a $1.5 \%$ agarose gel and were visualized by ethidium bromide staining. Image density was quantified with a FluoroImager SI (Amersham Pharmacia Biotech.). 
A

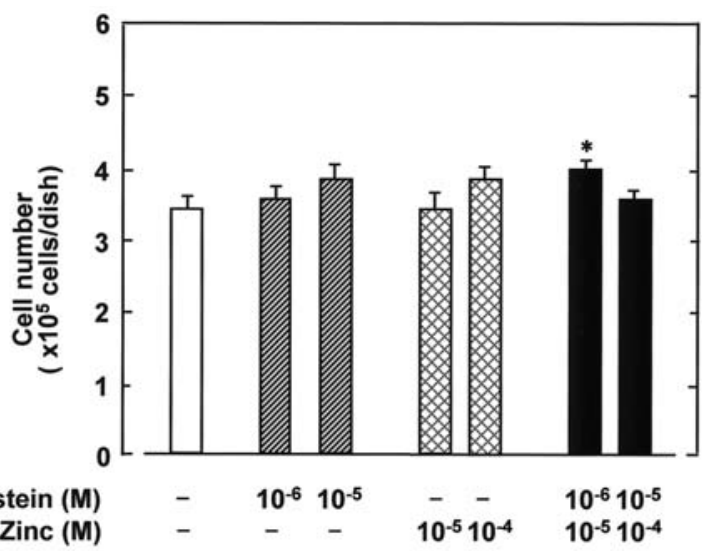

B

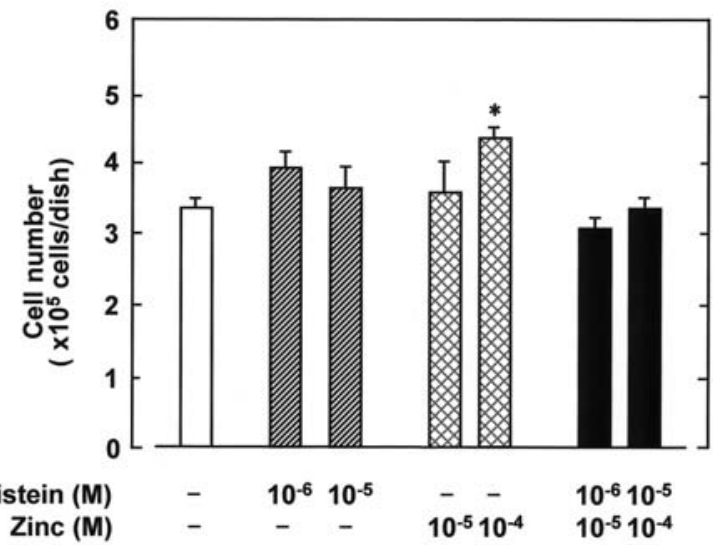

Figure 1. Effects of genistein and zinc on growth of osteoblastic MC3T3-E1 cells. (A) Osteoblastic cells $\left(1 \times 10^{5}\right)$ were cultured for $72 \mathrm{~h}$ in medium containing either vehicle, genistein $\left(10^{-6}\right.$ or $\left.10^{-5} \mathrm{M}\right)$, zinc sulfate $\left(10^{-5}\right.$ or $\left.10^{-4}\right)$ or genistein $\left(10^{-6}\right.$ or $\left.10^{-5} \mathrm{M}\right)$ plus zinc sulfate $\left(10^{-5}\right.$ or $\left.10^{-4}\right)$ in the presence of $10 \%$ FBS. (B) Cells with subconfluency were cultured for $72 \mathrm{~h}$ in medium containing either vehicle, genistein $\left(10^{-6}\right.$ or $\left.10^{-5} \mathrm{M}\right)$, zinc sulfate $\left(10^{-5}\right.$ or $\left.10^{-4}\right)$, or genistein $\left(10^{-6}\right.$ or $\left.10^{-5} \mathrm{M}\right)$ plus zinc sulfate $\left(10^{-5}\right.$ or $\left.10^{-4}\right)$, without $10 \%$ FBS. After trypsinization of the cells in each culture dish, cells were collected and counted. Each value is the mean \pm SEM of six cultures. ${ }^{*} \mathrm{P}<0.01$ compared with the control (none) value.

\section{A. Protein}

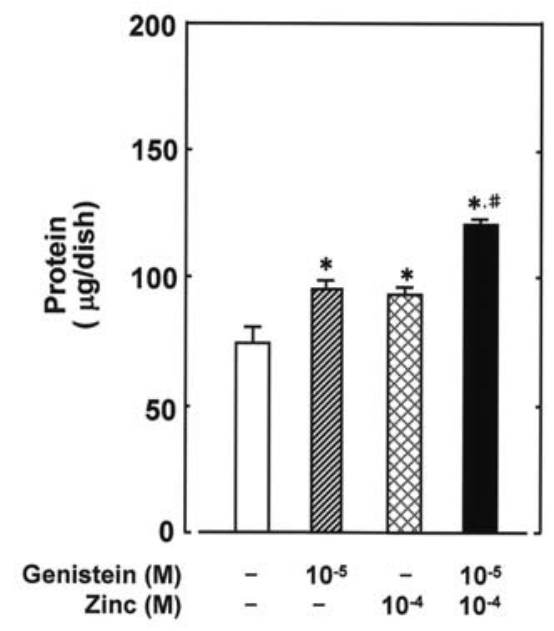

Alizarin red staining. Osteoblastic MC3T3-E1 cells (1.0x10 cells) were cultured for $72 \mathrm{~h}$ in a $\alpha$-MEM containing $10 \%$ FBS. Cells with subconfluency were changed to a Dullbecco's modified essential medium (DMEM) containing ascorbic acid $(100 \mu \mathrm{g} / \mathrm{ml})$ and $4 \mathrm{mM} \beta$-glycerophosphate in the presence or absence of genistein, zinc sulfate, or genistein plus zinc sulfate with $10 \%$ FBS. After medium change, cells were cultured for 7,14 , or 21 days. The medium was changed every 3 days. At each time point, cells were rinsed with PBS, and fixed on ice with $70 \%$ ethanol for $15 \mathrm{~min}$ for alizarin red staining of calcium (30). The alizarin red solution (40 mM, $\mathrm{pH}$ 4.2) was filtered through Whatman paper and applied to the fixed wells for $30 \mathrm{~min}$ at room temperature. Nonspecific staining was removed by several washes in water.

Statistical analysis. Data are expressed as the mean \pm SEM. Statistical differences were analyzed using a Student's t-test. P-values $<0.05$ were considered to indicate statistically significant differences. The ANOVA multiple comparison test was used to compare the treatment group.

\section{Results}

Effect of genistein and zinc on the proliferation of osteoblastic MC3T3-E1 cells. The effect of genistein and zinc sulfate on the proliferation of osteoblastic MC3T3-E1 cells reaching subconfluent monolayers was examined. Osteoblastic cells were cultured for $72 \mathrm{~h}$ in medium containing either vehicle, genistein $\left(10^{-6}\right.$ or $\left.10^{-5} \mathrm{M}\right)$, zinc sulfate $\left(10^{-5}\right.$ or $\left.10^{-4} \mathrm{M}\right)$, or genistein $\left(10^{-6}\right.$ or $\left.10^{-5} \mathrm{M}\right)$ plus zinc sulfate $\left(10^{-5}\right.$ or $\left.10^{-4} \mathrm{M}\right)$ with $10 \%$ FBS (Fig. 1A). The proliferation of osteoblastic cells was significantly increased in the presence of genistein $\left(10^{-6} \mathrm{M}\right)$ plus zinc sulfate $\left(10^{-5} \mathrm{M}\right)$. The stimulatory effect of genistein plus zinc sulfate on cell proliferation was not observed when the cells with subconfluency were cultured for $72 \mathrm{~h}$ without $10 \%$ FBS (Fig. 1B). A culture with $10^{-4} \mathrm{M}$ zinc sulfate caused a significant

\section{B. Alkaline phosphatase}

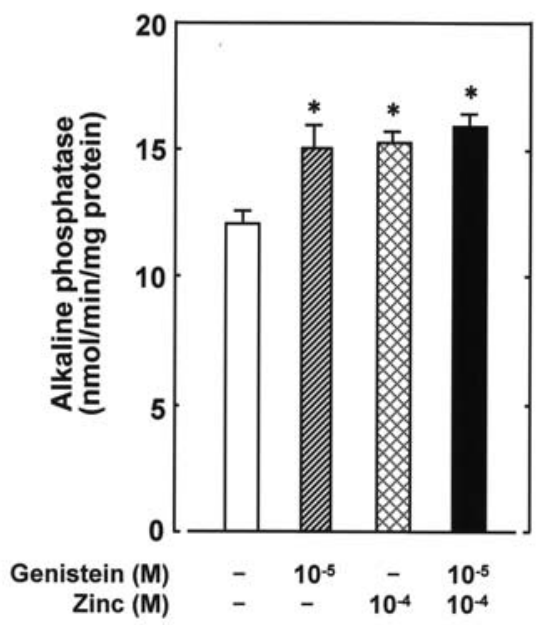

Figure 2. Effects of genistein and zinc on protein content and alkaline phosphatase activity in osteoblastic MC3T3-E1 cells. Osteoblastic cells (1x10 5 ) were cultured for $72 \mathrm{~h}$ in a medium containing $10 \%$ FBS. After culturing, cells with subconfluency were cultured for $48 \mathrm{~h}$ in medium containing either vehicle, genistein $\left(10^{-5} \mathrm{M}\right)$, zinc sulfate $\left(10^{-4}\right)$ or genistein $\left(10^{-5} \mathrm{M}\right)$ plus zinc sulfate $\left(10^{-4}\right)$ without $10 \%$ FBS. Cells were washed with PBS and scraped to determine protein content and alkaline phosphatase activity. Each value is the mean $\pm \mathrm{SEM}$ of six cultures. ${ }^{*} \mathrm{P}<0.01$ compared with the control (none) value. ${ }^{*} \mathrm{P}<0.01$ compared with the value obtained from genistein or zinc alone. 
A. Runx2

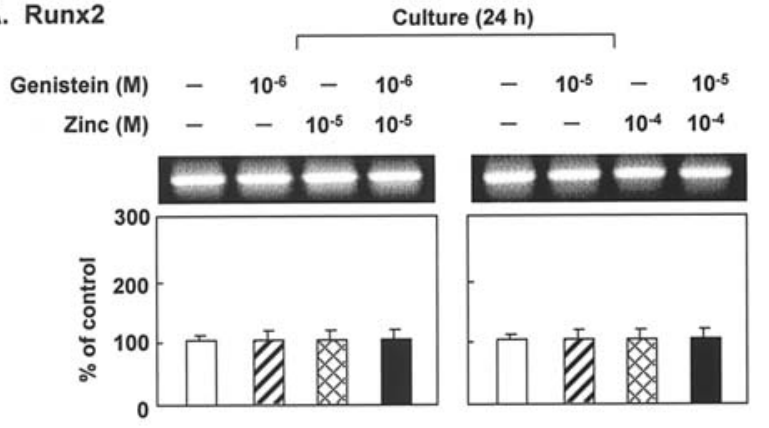

Culture $(48 \mathrm{~h})$

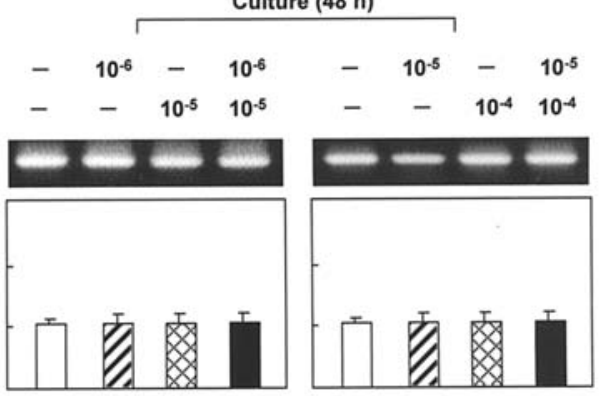

B. G3PDH

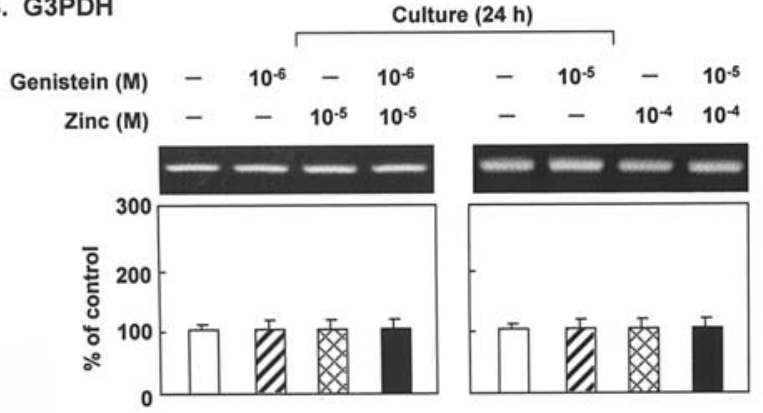

Culture (48 h)

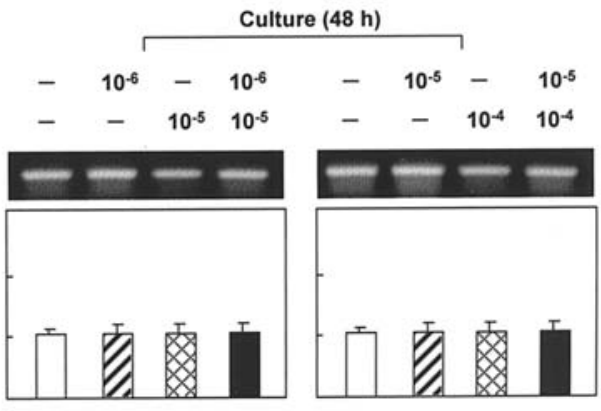

Figure 3. Effects of genistein and zinc on Runx2 or G3PDH mRNA expression in osteoblastic MC3T3-E1 cells using RT-PCR analysis. Osteoblastic cells $\left(1 \times 10^{5}\right)$ were cultured for $72 \mathrm{~h}$ in a medium containing $10 \%$ FBS. After culturing, cells with subconfluency were cultured for 24 or $48 \mathrm{~h}$ in medium containing either vehicle, genistein $\left(10^{-6}\right.$ or $\left.10^{-5} \mathrm{M}\right)$, zinc sulfate $\left(10^{-5}\right.$ or $\left.10^{-4}\right)$, or genistein $\left(10^{-6}\right.$ or $\left.10^{-5} \mathrm{M}\right)$ plus zinc sulfate $\left(10^{-5}\right.$ or $\left.10^{-4}\right)$, without $10 \%$ FBS. Total RNAs $(4 \mu \mathrm{g})$ isolated from the cells were analyzed using RT-PCR with Runx2- or G3PDH-specific primer. The housekeeping gene G3PDH mRNA was used as an internal control by ethidium bromide staining. The figure shows one of five experiments with separate samples. The densitometric data for Runx2 or G3PDH mRNA expression represents $\%$ of control. These data were not significant as compared to that of control.

\section{A. $\alpha 1(\mathrm{I})$ collagen}

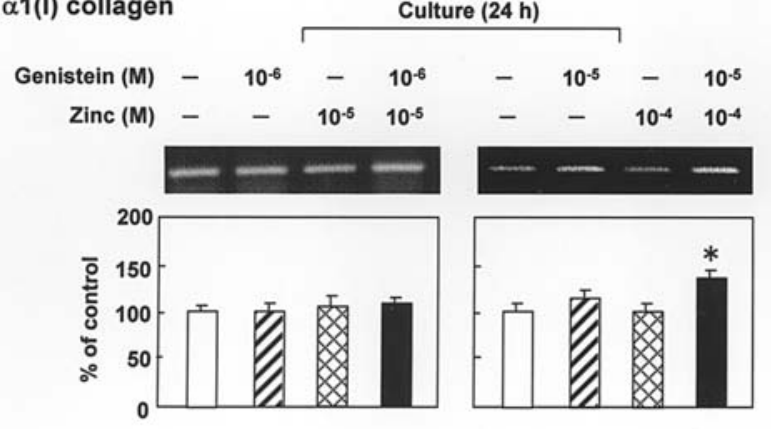

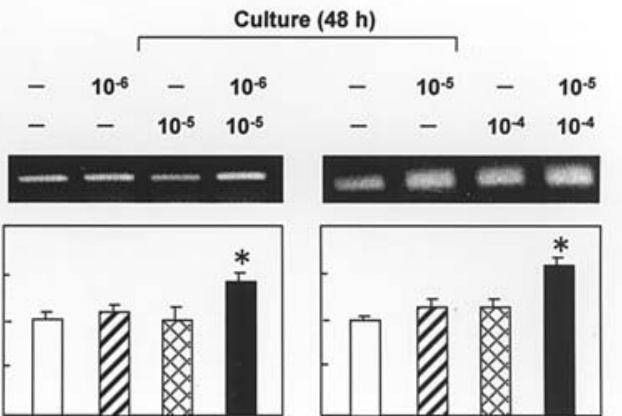

B. Alkaline phosphatase

Culture $(24 \mathrm{~h})$
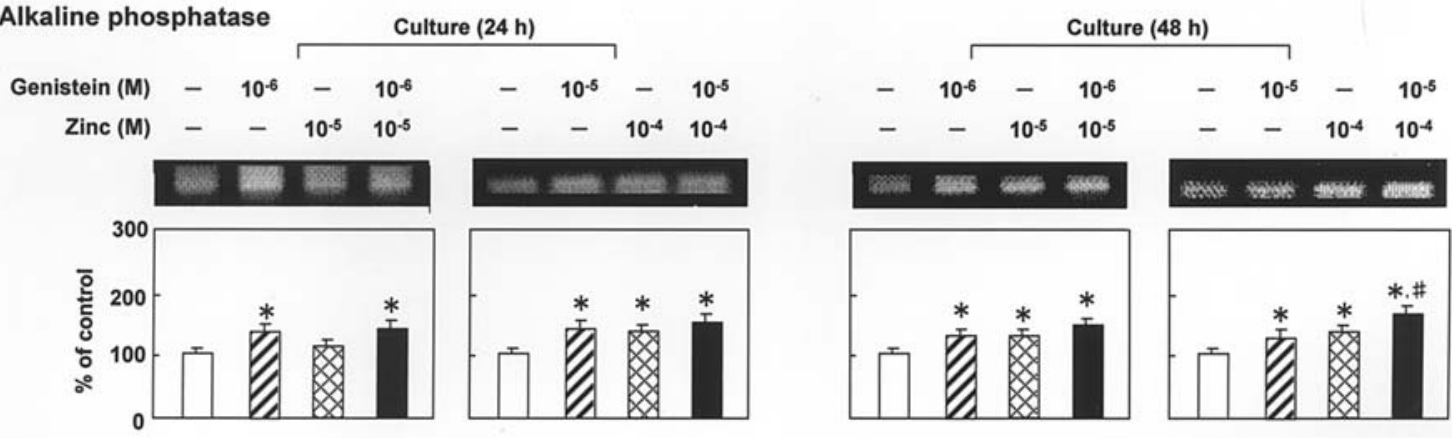

Figure 4. Effects of genistein and zinc on $\alpha 1$ (I) collagen or alkaline phosphatase mRNA expression in osteoblastic MC3T3-E1 cells using RT-PCR analysis. Osteoblastic cells $\left(1 \times 10^{5}\right)$ were cultured for $72 \mathrm{~h}$ in a medium containing $10 \% \mathrm{FBS}$. After culturing, cells with subconfluency were cultured for 24 or $48 \mathrm{~h}$ in medium containing either vehicle, genistein $\left(10^{-6}\right.$ or $\left.10^{-5} \mathrm{M}\right)$, zinc sulfate $\left(10^{-5}\right.$ or $\left.10^{-4}\right)$, or genistein $\left(10^{-6}\right.$ or $\left.10^{-5} \mathrm{M}\right)$ plus zinc sulfate $\left(10^{-5}\right.$ or $\left.10^{-4}\right)$, without $10 \%$ FBS. Total RNAs $(4 \mu \mathrm{g})$ isolated from the cells were analyzed using RT-PCR with $\alpha 1(\mathrm{I})$ collagen- or alkaline phosphatase-specific primers. The figure shows one of five experiments with separate samples. The densitometric data for $\alpha 1(\mathrm{I})$ collagen or alkaline phosphatase mRNA expression represents $\%$ of control. ${ }^{*} \mathrm{P}<0.01$ compared to the control (none) value. ${ }^{~} \mathrm{P}<0.01$ compared to the value obtained from genistein or zinc alone. 

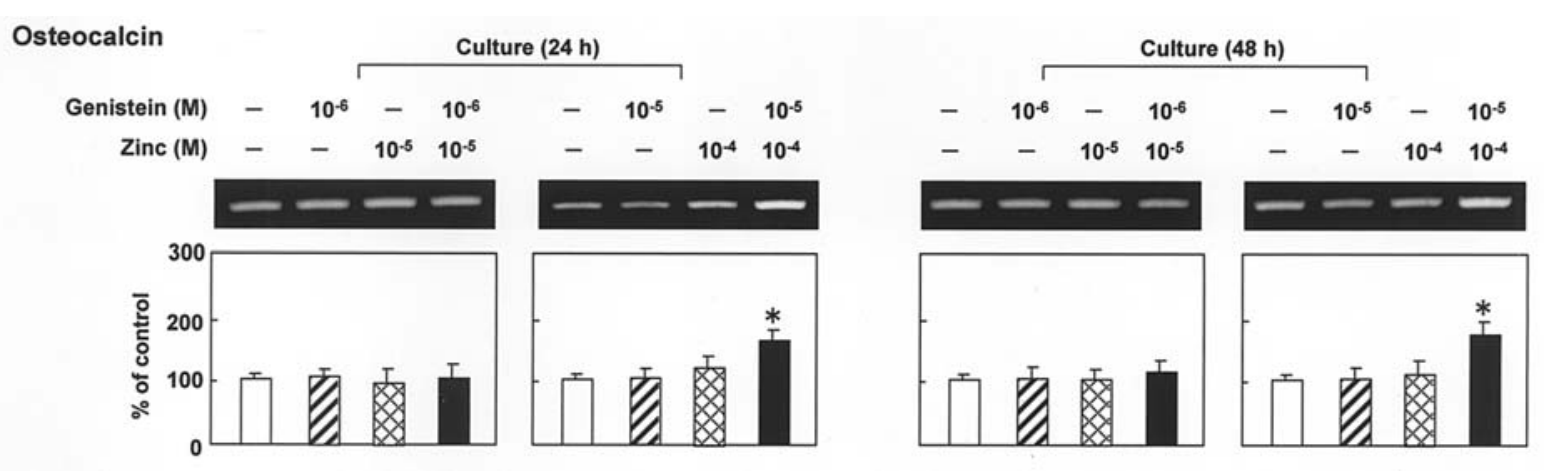

Figure 5. Effects of genistein and zinc on osteocalcin mRNA expression in osteoblastic MC3T3-E1 cells using RT-PCR analysis. Osteoblastic cells (1x105) were cultured for $72 \mathrm{~h}$ in a medium containing $10 \%$ FBS. After culturing, cells with subconfluency were cultured for 24 or $48 \mathrm{~h}$ in medium containing either vehicle, genistein $\left(10^{-6}\right.$ or $\left.10^{-5} \mathrm{M}\right)$, zinc sulfate $\left(10^{-5}\right.$ or $\left.10^{-4}\right)$, or genistein $\left(10^{-6}\right.$ or $\left.10^{-5} \mathrm{M}\right)$ plus zinc sulfate $\left(10^{-5}\right.$ or $\left.10^{-4}\right)$, without $10 \%$ FBS. Total RNAs $(4 \mu \mathrm{g})$ isolated from the cells were analyzed using RT-PCR with osteocalcin-specific primer. The figure shows one of five experiments with separate samples. The densitometric data for osteocalcin mRNA expression represents $\%$ of control. ${ }^{*} \mathrm{P}<0.01$ compared to the control (none) value.
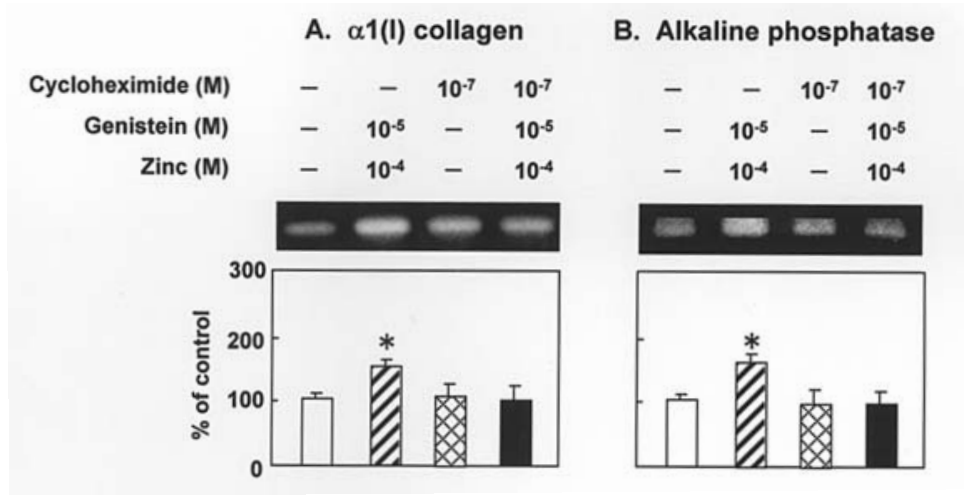

\section{Osteocalcin}

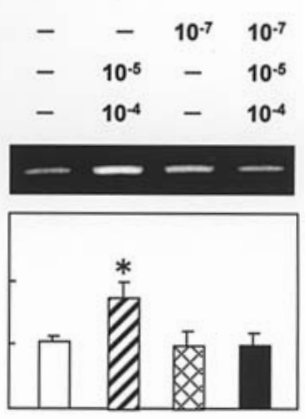

Figure 6. Effects of cycloheximide on the genistein- and zinc-induced increases in $\alpha 1$ (I) collagen, alkaline phosphatase, and osteocalcin mRNA expression in osteoblastic MC3T3-E1 cells using RT-PCR analysis. Osteoblastic cells $\left(1 \times 10^{5}\right)$ were cultured for $72 \mathrm{~h}$ in a medium containing $10 \%$ FBS. After culturing, cells with subconfluency were cultured for $48 \mathrm{~h}$ in medium containing either vehicle, genistein $\left(10^{-5} \mathrm{M}\right)$ plus zinc sulfate $\left(10^{-4}\right)$, in the presence or absence of cycloheximide $\left(10^{-7} \mathrm{M}\right)$ without $10 \%$ FBS. Total RNAs $(4 \mu \mathrm{g})$ isolated from the cells were analyzed using RT-PCR with $\alpha 1(\mathrm{I})$ collagen-, alkaline phosphatase-, or osteocalcin-specific primers. The figure shows one of five experiments with separate samples. The densitometric data for mRNA expression represents $\%$ of control. ${ }^{*} \mathrm{P}<0.01$ compared to the control (none) value.

increase in cell number when cells with subconfluency were cultured for $72 \mathrm{~h}$ without FBS.

Effect of genistein and zinc on biochemical components in osteoblastic MC3T3-E1 cells. Osteoblastic cells were cultured for $72 \mathrm{~h}$ in medium containing $10 \%$ FBS. Cells with subconfluency were cultured for $48 \mathrm{~h}$ in medium containing either vehicle, genistein $\left(10^{-5} \mathrm{M}\right)$, zinc sulfate $\left(10^{-4} \mathrm{M}\right)$, or genistein $\left(10^{-5} \mathrm{M}\right)$ plus zinc sulfate $\left(10^{-4} \mathrm{M}\right)$. The change in protein content and alkaline phosphatase activity in osteoblastic cells was examined. The protein content in the cells was significantly increased with a culture of genistein $\left(10^{-5} \mathrm{M}\right)$ or zinc sulfate $\left(10^{-4} \mathrm{M}\right)$. These increases were significantly enhanced with a culture of the combination of genistein $\left(10^{-5} \mathrm{M}\right)$ and zinc sulfate $\left(10^{-4} \mathrm{M}\right)$ (Fig. 2A). Alkaline phosphatase activity in osteoblastic cells was significantly increased with a culture of genistein $\left(10^{-5} \mathrm{M}\right)$, zinc sulfate $\left(10^{-4} \mathrm{M}\right)$, or genistein $\left(10^{-5} \mathrm{M}\right)$ plus zinc sulfate $\left(10^{-4} \mathrm{M}\right)$ (Fig. 2B). The combination of genistein $\left(10^{-5} \mathrm{M}\right)$ and zinc sulfate $\left(10^{-4} \mathrm{M}\right)$ did not significantly enhance the effect of each factor on the enzyme activity.
Effect of genistein and zinc on gene expression in osteoblastic MC3T3-E1 cells. Osteoblastic cells with subconfluency were cultured for 24 or $48 \mathrm{~h}$ in medium containing either vehicle, genistein $\left(10^{-6}\right.$ or $\left.10^{-5} \mathrm{M}\right)$, zinc sulfate $\left(10^{-5}\right.$ or $\left.10^{-4}\right)$, or genistein $\left(10^{-6}\right.$ or $\left.10^{-5} \mathrm{M}\right)$ plus zinc sulfate $\left(10^{-5}\right.$ or $10^{-4}$ ) without $10 \%$ FBS. The expression of Runx 2 or G3PDH mRNA in the cells was not significantly changed in the presence of genistein $\left(10^{-6}\right.$ or $\left.10^{-5} \mathrm{M}\right)$, zinc sulfate $\left(10^{-5}\right.$ or $\left.10^{-4}\right)$ or genistein $\left(10^{-6}\right.$ or $\left.10^{-5} \mathrm{M}\right)$ plus zinc sulfate $\left(10^{-5}\right.$ or $\left.10^{-4}\right)$ (Fig. 3A and B). $\alpha 1(\mathrm{I})$ collagen mRNA expression was significantly increased with a culture of genistein $\left(10^{-6} \mathrm{M}\right)$ plus zinc sulfate $\left(10^{-5} \mathrm{M}\right)$ or genistein $\left(10^{-5} \mathrm{M}\right)$ plus zinc sulfate $\left(10^{-4} \mathrm{M}\right)$ for $48 \mathrm{~h}$, although its gene expression was not significantly changed with a culture of genistein $\left(10^{-6}\right.$ or $\left.10^{-5} \mathrm{M}\right)$ or zinc sulfate $\left(10^{-5}\right.$ or $\left.10^{-4}\right)$ alone (Fig. 4A). Alkaline phosphatase mRNA expression was significantly increased with a culture for $48 \mathrm{~h}$ in the presence of genistein $\left(10^{-6}\right.$ or $10^{-5} \mathrm{M}$ ) or zinc sulfate $\left(10^{-5}\right.$ or $\left.10^{-4}\right)$ (Fig. 4B). The effect of genistein $\left(10^{-5} \mathrm{M}\right)$ or zinc sulfate $\left(10^{-4} \mathrm{M}\right)$ in increasing alkaline phosphatase mRNA expression was significantly enhanced with the combination of genistein $\left(10^{-5} \mathrm{M}\right)$ and zinc 


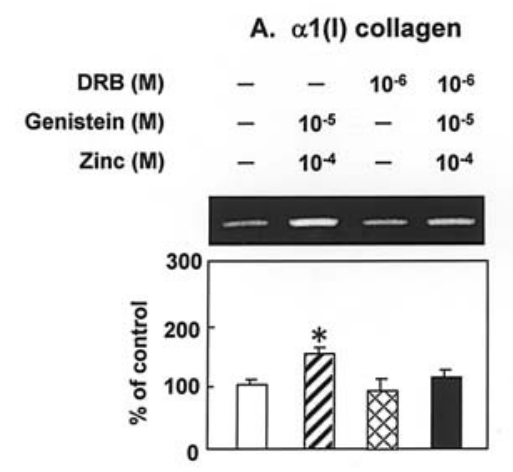

B. Alkaline phosphatase
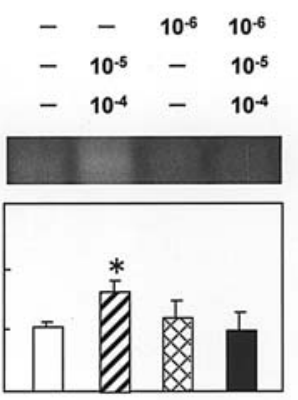

C. Osteocalcin

$-\quad-10^{-6} \quad 10^{-6}$

$-10^{-5}-10^{-5}$

$-10^{-4}-10^{-4}$

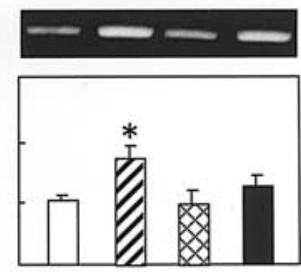

Figure 7. Effects of DRB on the genistein and zinc-induced increases in $\alpha 1(\mathrm{I})$ collagen, alkaline phosphatase, and osteocalcin mRNA expression in osteoblastic MC3T3-E1 cells using RT-PCR analysis. Osteoblastic cells $\left(1 \times 10^{5}\right)$ were cultured for $72 \mathrm{~h}$ in a medium containing $10 \%$ FBS. After culture, cells with subconfluency were cultured for $48 \mathrm{~h}$ in medium containing either vehicle, genistein $\left(10^{-5} \mathrm{M}\right)$ plus zinc sulfate $\left(10^{-4}\right)$, in the presence or absence of DRB $\left(10^{-6} \mathrm{M}\right)$ without $10 \%$ FBS. Total RNAs $(4 \mu \mathrm{g})$ isolated from the cells were analyzed using RT-PCR with $\alpha 1(\mathrm{I})$ collagen-, alkaline phosphatase-, or osteocalcin-specific primers. The figure shows one of five experiments with separate samples. The densitometric data for mRNA expression represents $\%$ of control. ${ }^{*} \mathrm{P}<0.01$ compared to the control (none) value.

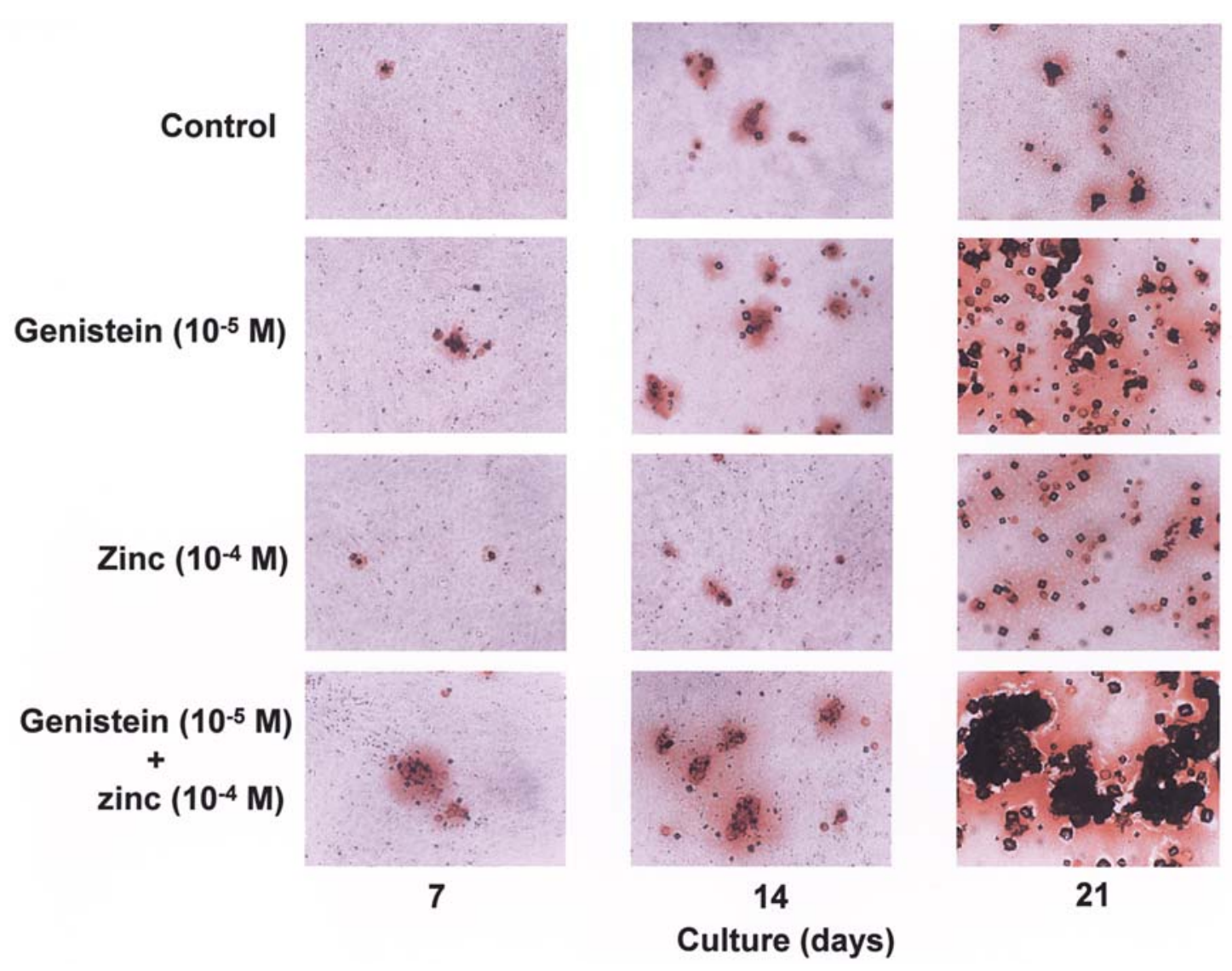

Figure 8. Effects of genistein and zinc sulfate on mineralization in osteoblastic MC3T3-E1 cells. Osteoblastic cells $\left(1 \times 10^{5}\right)$ were cultured for 72 h in medium containing $10 \%$ FBS. After culturing, cells with subconfluency were cultured for 7, 14, or 21 days in medium containing either vehicle, genistein (10-5 M), zinc sulfate $\left(10^{-4} \mathrm{M}\right)$, or genistein $\left(10^{-5} \mathrm{M}\right)$ plus zinc sulfate $\left(10^{-4} \mathrm{M}\right)$ with $10 \%$ FBS. Cells were washed with PBS and alizarin red stained. The figure shows one of five experiments with separate cultures.

sulfate $\left(10^{-4} \mathrm{M}\right)$ for $48 \mathrm{~h}$ (Fig. 4B). Osteocalcin mRNA expression in osteoblastic cells was significantly increased with a culture of genistein $\left(10^{-5} \mathrm{M}\right)$ plus zinc sulfate $\left(10^{-4} \mathrm{M}\right)$ for 24 or $48 \mathrm{~h}$ (Fig. 5). Genistein $\left(10^{-5} \mathrm{M}\right)$ or zinc sulfate $\left(10^{-4} \mathrm{M}\right)$ alone did not have a significant effect on osteocalcin mRNA expression in the cells.

The effect of cycloheximide, an inhibitor of protein synthesis, or DRB, an inhibitor of transcription activity, on genistein as well as the zinc sulfate-induced increase in gene expression in osteoblastic cells were examined. The effect of the combination of genistein and zinc sulfate in enhancing $\alpha 1$ (I) collagen, alkaline phosphatase, or osteocalcin mRNA expression was completely prevented in the presence of cycloheximide (10-7 M) (Fig. 6) or DRB (10-6 M) (Fig. 7).

Effect of genistein and zinc on mineralization in osteoblastic MC3T3-E1 cells. Osteoblastic cells with subconfluency were cultured for 7,14 , or 21 days in medium containing either 
vehicle, genistein $\left(10^{-5} \mathrm{M}\right)$, zinc sulfate $\left(10^{-4} \mathrm{M}\right)$, or genistein $\left(10^{-5} \mathrm{M}\right)$ plus zinc sulfate $\left(10^{-4} \mathrm{M}\right)$, and the mineralization was examined (Fig. 8). The results with alizarin red staining for calcium showed that the mineralization was significantly stimulated in the presence of genistein $\left(10^{-5} \mathrm{M}\right)$ or zinc sulfate $\left(10^{-4} \mathrm{M}\right)$. The enhancement of mineralization was observed from 14 days of culture. The effect was markedly enhanced with a 21-day culture in the presence of genistein or zinc sulfate. The combination of genistein and zinc sulfate caused a remarkable increase in mineralization as compared with that of genistein or zinc sulfate alone.

\section{Discussion}

The intake of the combination of dietary genistein and zinc prevents bone loss in ovariectomized rats which are model animals of osteoporosis (21). Genistein or zinc has been shown to activate aminoacyl-tRNA synthase, the rate-limiting enzyme of translational protein synthesis, and to stimulate protein synthesis in osteoblastic MC3T3-E1 cells $(8,13,16)$. The cellular mechanism by which the combination of genistein and zinc has an anabolic effect on bone components in rats has not been determined. The present study demonstrates that the combination of genistein and zinc has a synergistic effect on gene expression and mineralization in osteoblastic MC3T3-E1 cells in vitro.

The combination of genistein and zinc was found to have an additive effect on protein content in osteoblastic cells in vitro. This effect may involve the activation of aminoacyltRNA synthase by genistein and zinc, since these factors can increases the enzyme activity in the cytosol of osteoblastic cells in vitro $(8,15,16)$.

Alkaline phosphatase is an enzyme marker of osteoblasts, and the enzyme participates in bone mineralization (31). $\alpha 1$ (I) collagen is a matrix protein that is related to bone formation and mineralization in osteoblast lineage cells (32). Osteocalcin is a bone matrix protein containing $\gamma_{2}$-carboxyglutamin acid which is synthesized in osteoblasts, and is the protein involved in mineralization (32). The expression of alkaline phosphatase, $\alpha 1$ (I) collagen and osteocalcin mRNAs in osteoblastic cells was significantly enhanced with a culture of the combination of genistein and zinc as compared to the effect of each factor. This finding demonstrates that the combination of genistein and zinc has a synergistic effect on gene expression in osteoblastic cells.

The effect of the combination of genistein and zinc on gene expression in osteoblastic cells was completely prevented in the presence of cycloheximide, an inhibitor of protein synthesis, and DRB, an inhibitor of transcriptional activity. This result suggests that the combination of genistein and zinc stimulates the transcriptional process in osteoblastic cells. Genistein or zinc has a stimulatory effect on protein synthesis at the transcriptional process $(8,13,16)$. Presumably, the combination of genistein and zinc stimulates both transcriptional and translational activities in osteoblastic cells. Each factor activates aminoacyl-tRNA synthetase at the transcriptional process in osteoblastic cells. It is speculated that genistein or zinc has an effect on the binding of the transcriptional factor to DNA in osteoblastic cells.
A culture with genistein or zinc was found to have a stimulatory effect on the mineralization in osteoblastic cells. The combination of genistein and zinc synergistically enhanced mineralization in osteoblastic cells. This finding suggests that the combination of genistein and zinc can effectively enhance bone mineralization, thereby increasing bone mass. The combination of genistein and zinc may be a useful tool in the prevention and therapy of osteoporosis.

In conclusion, it has been demonstrated that the combination of genistein and zinc has a synergistic effect on gene expression and mineralization in osteoblastic cells in vitro.

\section{References}

1. Nishimoto SK, Chang C-H, Gendler E, Stryker WF and Nimi ME: The effect of aging on bone formation in rats: biochemical and histological evidence for decreased bone formation capacity. Calcif Tissue Int 37: 617-624, 1985

2. Schapira C, Slinn S, Sarid M, Mokadai S, Kabala A and Silberman M: Calcium and vitamin D enriched diets increase and preserve vertebral mineral content in aging laboratory rats. Bone 16: 575-582, 1995 .

3. Wild RA, Buchamain JR, Myers C and Demers LM: Declining adrenal androgen and association with bone loss in aging women. Proc Soc Exp Biol Med 186: 335-360, 1987.

4. Cooper C and Melton J III: Epidemiology of osteoporosis. Trends Endocrinol Metab 3: 224-229, 1995.

5. Bonjour J-P, Schurch M-A and Rozzori R: Nutritional aspects of hip fracture. Bone 18: 1395-1445, 1996.

6. Yamaguchi M: Isoflavone and bone metabolism: Its cellular mechanism and preventive role in bone loss. J Health Sci 48: 209-222, 2002.

7. Sugimoto $\mathrm{E}$ and Yamaguchi M: Anabolic effect of genistein in osteoblastic MC3T3-E1 cells. Int J Mol Med 5: 515-520, 2000.

8. Yamaguchi M and Sugimoto E: Stimulatory effect of genistein and daidzein on protein synthesis in osteoblastic MC3T3-E1 cells: Activation of aminoacyl-tRNA synthase. Mol Cell Biochem 214: 97-102, 2000.

9. Yamaguchi M and Gao YH: Inhibitory effect of genistein on bone resorption in tissue culture. Biochem Pharmacol 55: 71-76, 1998.

10. Gao HY and Yamaguchi M: Inhibitory effect of genistein on osteoclast-like cell formation in mouse marrow cultures. Biochem Pharmacol 58: 767-772, 1999.

11. Blair HC, Jordan SE, Peterson TG and Barnes S: Variable effects of tyrosine kinase inhibitors on avian osteoclastic activity and reduction of bone loss in ovariectomized rats. J Cell Biochem 61: 629-637, 1996.

12. Yamaguchi M, Oishi H and Suketa Y: Stimulatory effect of zinc on bone formation in tissue culture. Biochem Pharmacol 36: 4007-4012, 1987.

13. Hashizume M and Yamaguchi M: Stimulatory effect of $B-$ alanyl-L-histidinato zinc on cell proliferation is dependent on protein synthesis in osteoblastic MC3T3-E1 cells. Mol Cell Biochem 122: 59-64, 1991.

14. Kishi S and Yamaguchi M: Inhibitory effect of zinc compounds on osteoclast-like cell formation in mouse marrow cultures. Biochem Pharmacol 48: 1225-1230, 1994.

15. Yamaguchi $\mathrm{M}$ and Uchiyama S: Receptor activator of NF-kB ligand-stimulated osteoclastogenesis in mouse marrow culture is suppressed by zinc in vitro. Int J Mol Med 14: 81-85, 2004.

16. Yamaguchi M, Kishi S and Hasizume M: Effect of zincchelating dipeptides on osteoblastic MC3T3-E1 cells: Activator of aminoacyl-tRNA synthase. Peptides 15: 1367-1371, 1994.

17. Kishi S, Segawa Y and Yamaguchi M: Histomorphological confirmation of the preventive effect of $\beta$-alanyl-L-histidinato zinc on bone loss in ovariectomized rats. Biol Pharm Bull 17: 862-865, 1994.

18. Yamaguchi M and Gao YH: Anabolic effect of genistein and genistin on bone metabolism in the femoral-metaphyseal tissues of elderly rats: The genistein effect is enhanced by zinc. Mol Cell Biochem 178: 377-382, 1998.

19. Yamaguchi M, Gao YH and Ma ZJ: Synergistic effect of genistein and zinc on bone components in the femoralmetaphyseal tissues of female rats. J Bone Miner Metab 18: $77-83,2000$. 
20. Gao YH and Yamaguchi M: Zinc enhancement of genistein's anabolic effect on bone components in elderly female rats. Gen Pharmacol 32: 199-202, 1998.

21. Ma ZJ, Shimanuki S, Igarashi A, Kawasaki Y and Yamaguchi M: Preventive effect of dietary fermented soybean on bone loss in ovariectomized rats: Enhancement with isoflavone and zinc supplementation. J Health Sci 46: 263-268, 2000.

22. Yamaguchi M, Igarashi A, Sakai M, Degawa $H$ and Ozawa $Y$ : Prolonged intake of dietary fermented isoflavone-rich soybean rein-forced with zinc effects circulating bone biochemical markers in aged individuals. J Health Sci 51: 191-196, 2005.

23. Lowry OH, Rosebrough NJ, Farr AL and Randall RJ: Protein measurement with the Folin phenol reagent. J Biol Chem 193: 265-275, 1951.

24. Walter K and Schutt C: Acid and alkaline phosphatase in serum. In: Methods of Enzymatic Analysis. Bergmeyer HV (ed). Vols. 1-2, Academic Press, New York, pp856-860, 1965.

25. Chamczynshi $P$ and Sacchi N: Single-step method of RNA isolation by acid guanidium thiocyanate-phenol-chloroform extraction. Anal Biochem 162: 156-159, 1987.

26. Sohn KY, Maity SN and de Crombrugghe B: Studies on the structure of CBF-A isoform generated from an alternatively spliced RNA. Gene 139: 147-153, 1994.

27. Luppen CA, Smith E, Spevak L, Boshey AL and Frenhel B: Bone morphogenetic protein-2 restores mineralization in glucocorticoid-inhibited MC3T3-E1 osteoblast cultures. J Bone Miner Res 18: 1186-1197, 2003.
28. Wilcox FH and Tatlor BA: Genetics of the Akp-2 locus for alkaline phosphatase of liver, kidney, bone, and placenta in the mouse. Linkage with the Ahd-1 locus on chromosome 4. J Hered 72: 387-390, 1981.

29. Desbois C, Hogue DA and Karsenty G: The mouse osteocalcin gene cluture contains three genes with two separate spatial and temporal patterns of expression. J Biol Chem 269: 1183-1190, 1994.

30. Kamiya N, Jihho A, Kimata K, Dansky C, Shimizu K and Watanabe H: Establishment of a novel chondorocytic cell line N1511 derived from p53 null mice. J Bone Miner Res 17: 1832-1842, 2002.

31. Majeska RJ and Wuthier RE: Studies on matrix vesicles isolated from chick epiphyseal cartilage. Association of pyrophosphatase and ATPase activities with alkaline phosphatase. Biochim Biophys Acta 391: 51-60, 1975.

32. Lian JB, Stein GS, Cannalis E, Roky PG and Boskey AL: Bone formation: Osteoblast lineage cells, growth factor, matrix protein, and the mineralization process. In: Primer on the Metabolic Bone Diseases and Disorders of Mineral Metabolism. Favus MJ (ed). 4th edition, Lippincott Williams \& Wilkins Press, New York, pp14-29, 1999.

33. Price PA: Vitamin K-dependent formation of bone gla protein (osteocalcin) and its function. Vitam Horm 42: 65-108, 1985. 